\title{
FLIGHT SAFETY LEVEL IMPROVEMENT METHODOLOGY BASED ON THE PILOT MODEL
}

\author{
A.D. BARABASH ${ }^{1}$, S.F. BORODKIN ${ }^{1}$, M.A. KISELEV ${ }^{1}$, Yu.V. PETROV ${ }^{1}$ \\ ${ }^{1}$ Moscow State Technical University of Civil Aviation, Moscow, Russia
}

\begin{abstract}
Despite the regular efforts on the part of national regulators, the International Civil Aviation Organization and the International Air Transport Association (ICAO and IATA), as well as on the developers of aeronautical equipment, the vast majority of accidents and incidents continue to occur due to the human factor. With the course of time, aircraft design and reliability are steadily and significantly improving, nevertheless, the number of aviation accidents is happening more and more frequently, including accidents with serviceable aircraft. Considerable evidence is the fact that a Controlled Flight into Terrain (CFIT) remains one of the most common causes of aviation accidents. This is specified by a wide variety of problems that require the search for complex, interconnected solutions. Among these issues it is necessary to highlight the increasing sophistication of the aircraft as a technical system, as well as practically unchanged for more than half a century approaches to pilots training for the type and maintaining their qualifications based on pre-defined scenarios taking into consideration the previous experience of aircraft operation. One of the possible ways out of the situation may be the introduction of so-called concept of personnel training relying on the evidence-based training analysis (EBT) based not on the pursue to memorize a certain list of exercises but to develop each particular pilot's skills and competences that could help him cope with any unpredictable situation. The key feature of EBT lies in refocusing on the analysis of original causes of unsuccessful maneuvers (actions of the pilot) primarily in order to correct the wrong actions instead of repeatedly complying with the "correct sequence of actions". In this regard, the tools providing a continuous analysis of the pilot's actions to identify errors for the purpose of realigning (forming) the pilot's professional competencies in due time, are of paramount importance. The article describes the content of the methodology representing an ultimate goal to develop recommendations aimed at improving pilot's expertise based on generalized and personalized models of the pilot, as well as solving the inverse problem of flight dynamics using a comparative assessment of a particular pilot piloting quality.
\end{abstract}

Key words: flight safety, human factor, personnel training, evidence analysis, flight dynamics, pilot model.

\section{INTRODUCTION}

At present time the issue of flight safety still remains very actual taking into consideration the fact that the amount of aviation accidents hasn't reduced lately on average (Fig. 1). The analysis of the events mentioned above unequivocally implies the human factor predominance among other causes of aviation accidents [1]. On average approximately $80 \%$ of all causes of aviation accidents were accounted for by a human factor for over the period from 2009 to 2018. (Fig. 2). Thus, according to the data and reports of the State Aviation Supervision and the Intergovernmental Aviation Committee on the Flight Safety in Civil Aviation of the Russian Federation ${ }^{1}$ the most common causes of aviation ac-

\footnotetext{
1 The flight safety in civil aviation state of the party-states to the agreement on civil aviation and on the use of airspace in 2018. (2019). Interstate Aviation Committee. Available at: https://makiac.org/upload/iblock/4b6/bp-17-2.pdf (accessed:15.10.2021).
} 
cidents have become CIFT (17\%), flight crew's errors on take-off and landing (45\%), as well as loss of control in flight (11\%) (Fig. 3$)^{2}$.

Among the main reasons that contribute to keeping a high degree of the human factor in aviation accidents we should emphasize the following:

Firstly, these are the problems associated with both imperfection of the modern pilot training paradigm $^{3}$ and non-compliance of the material and technical base with the modern requirements $[2,3$, $4,5]$.
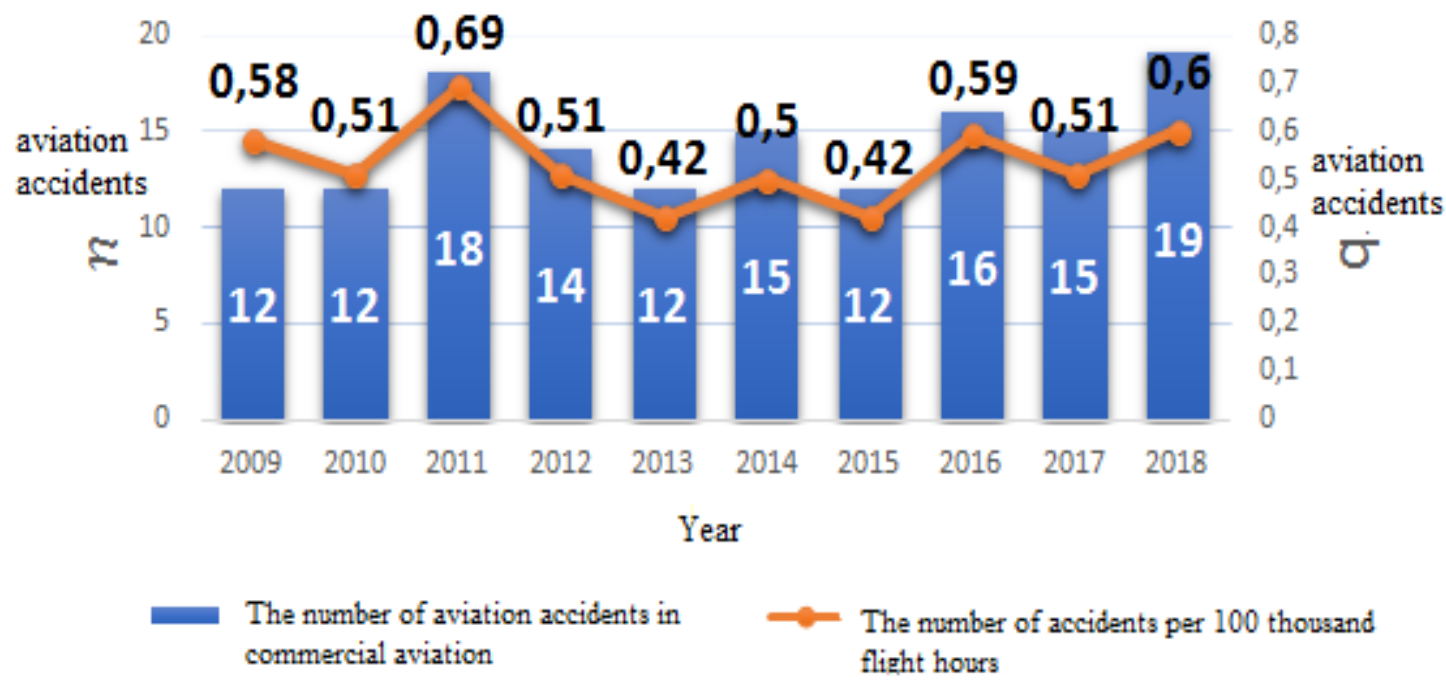

Fig. 1. Absolute and relative (number of accidents per 100 thousand flight hours) flight safety indicators for commercial air transportation of passengers and cargo in the Russian Federation for 2009-2018

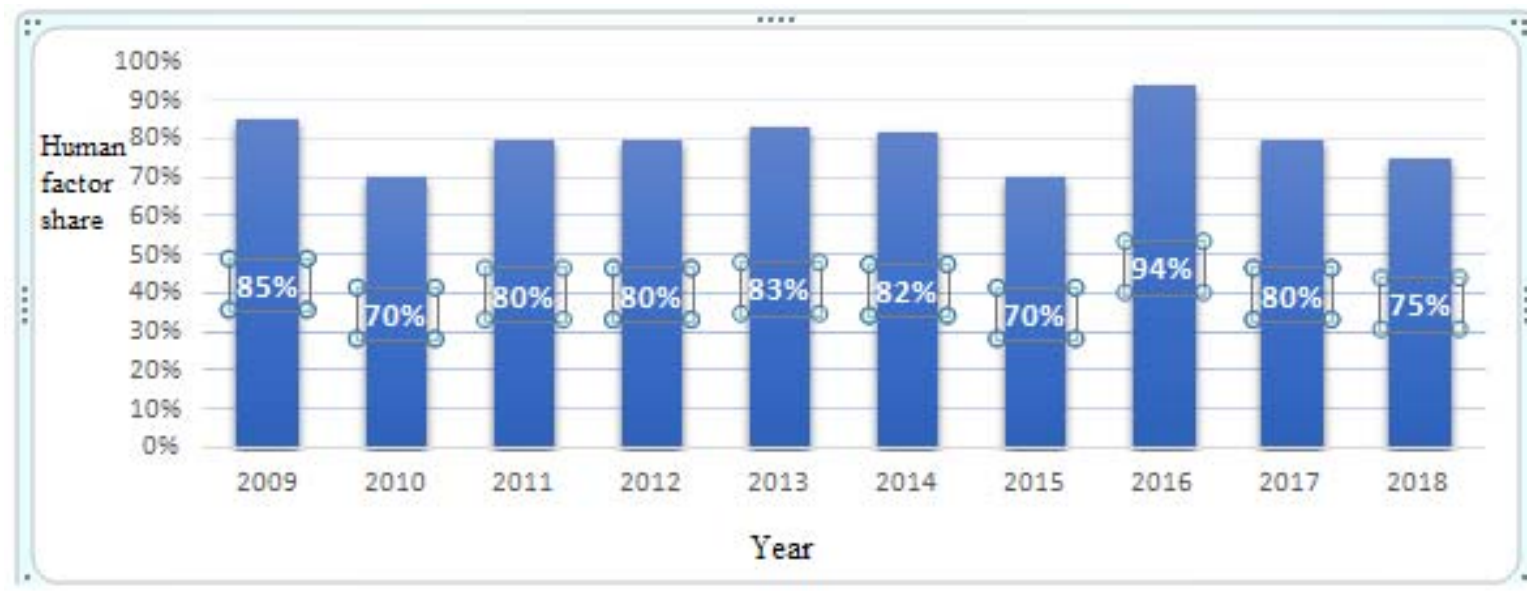

Fig. 2. The share of the human factor in aviation accidents (period 2009-2018) according to the annual reports of the Interstate Aviation Committee

\footnotetext{
2 The civil aviation of the Russian Federation 2018. Fight safety analysis. Department of the aviation safety inspection (2018). State Aviation Supervision. Available at: https://avia.rostransnadzor.ru/flight safety/flight safety analysis (accessed: 18.10.2021).

${ }^{3}$ Doc 9995 AN/497. (2013). Evidence-based Training Manual. 1st ed. International Civil Aviation Organization, 170 p.
} 


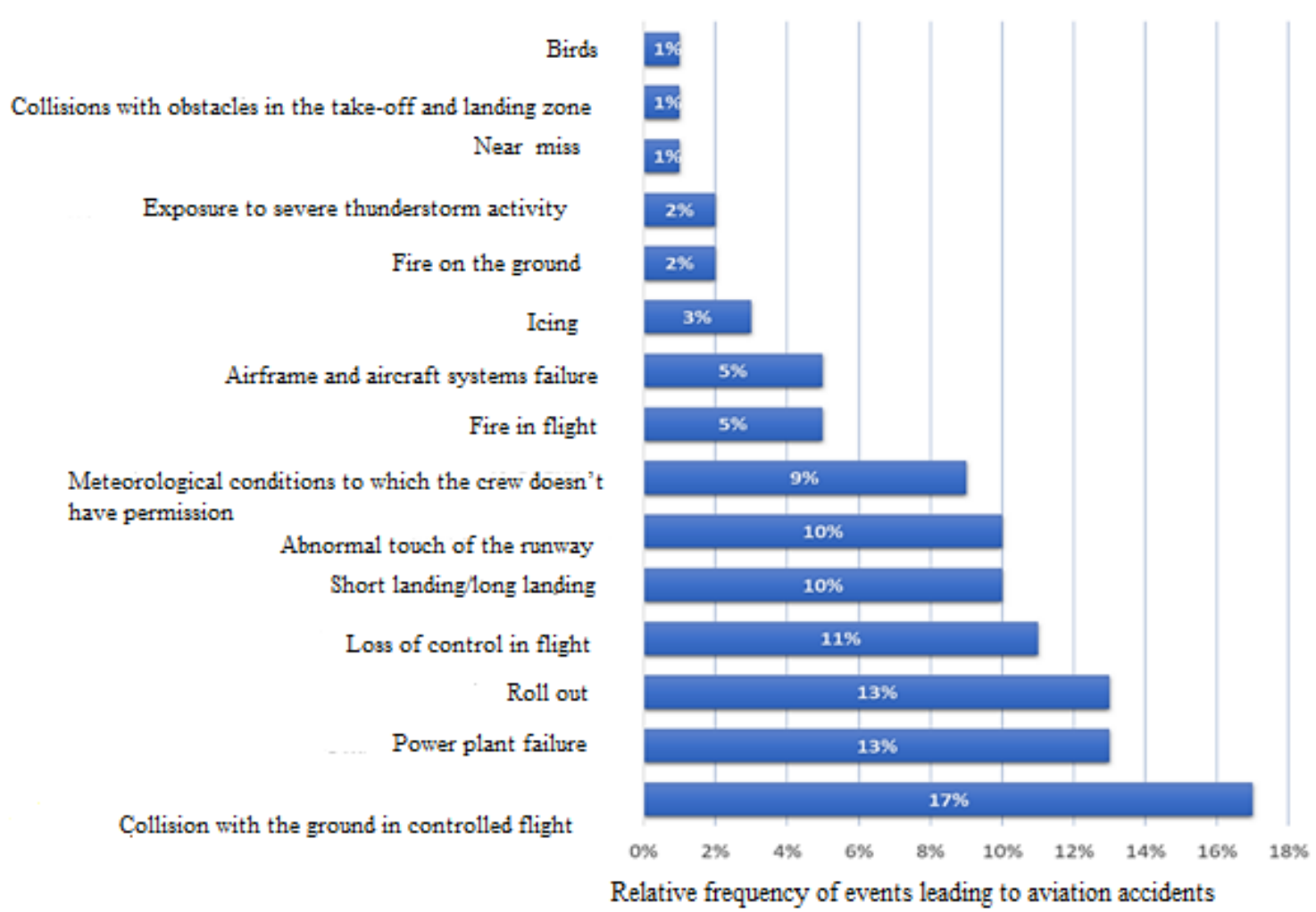

Fig. 3. The main types of events leading to aviation accidents with commercial aircraft (period 2001-2018)

Among the main reasons that contribute to keeping a high degree of the human factor in aviation accidents we should emphasize the following:

Firstly, these are the problems associated with both imperfection of the modern pilot training para$\operatorname{digm}^{4}$ and non-compliance of the material and technical base with the modern requirements $[2,3,4,5]$.

Secondly, these are the problems related to the increasing aircraft complexity and automatic systems significance. So, the more automation is used in-flight, the more the person controlling the aircraft gets adapted to the role of the operator, the less he remains a pilot trained to respond to the force majeure circumstances arising in flight [6]. The lack of comprehensive training for actions in case of any automatic system failure is sure to have a negative effect on the flight safety if such a failure occurs. Accidents on October 29, 2018 and March 10, 2019 with the Boeing 737-8200 (Boeing 737 MAX) aircraft can serve as a bright illustration when pilots were not properly trained to operate the new Maneuvering Characteristics Augmentation System (MCAS) adjusting the stabilizer angle for the purpose of reducing the pitch attitude with increase of the angle of attack ${ }^{5}$. At the same time it is obviously impossible to foresee all the scenarios of probable aviation accidents, especially in the conditions of the sophisticated aviation system, which complexity and high reliability actually mean that the subsequent flight accident can be completely unpredictable.

Thirdly, it is evident that competency of the educational institutions training staff and operator's flight services that provide training, assessment of knowledge and piloting proficiency is essential in forming the pilot's skills and expertise [7]. Subjectivity of instructor personnel in the process of pilots training and obtained skills assessment can cause lack of readiness of the pilot for a number of sit-

\footnotetext{
4 Doc 9995 AN/497. (2013). Evidence-based Training Manual. 1st ed. International Civil Aviation Organization, 170 p.

5 Komite Nasional Keselamatan Transportasi Republic of Indonesia. Aircraft accident investigation report. PT. Lion Mentari Airlines Boeing 737-8 (MAX); PK-LQP Tanjung Karawang, West Java Republic of Indonesia. Available at: https://reports.aviation-safety.net/2018/20181029-0_B38M_PK-LQP_PRELIMINARY.pdf (accessed: 11.01.2021).
} 
uations during flight operation. Besides, there is a problem of a frequently formal flight performance assessment of a particular pilot in airlines, merely relying on the express analysis of flight data when only parameters going beyond flight limits are recorded in accordance with the regulating documents. However, such an approach does not allow us to evaluate flight performance to a full extent as well as to give correct recommendations to the pilot, particularly to predict the possible fatal problems in the future flight operations.

The implementation of the evidence-based training (EBT) ${ }^{6}$ concept of personnel training can be considered as an effective way to resolve the problems outlined above. Evidence-based training (EBT) assumes the change of the pilot training methodology specifically refusal from training exclusively based on the scenarios in favor of development and assessing expertise to support more qualitative result upon completion of training. It is proposed that acquiring a limited number of certain competencies will enable the pilot to cope with unexpectedly unfamiliar and potentially hazardous situations in flight. Thus, it is necessary not to just replace partially an outdated set of critical scenarios for a new one, but to use event-based scenarios as a method and means for developing and evaluating the effectiveness of the crew's actions in terms of applying the required specific competencies. The potential of the similar approach is indicative of the above-mentioned Boeing 737 MAX 8 airplane accidents, namely, before the stated above disasters several Boeing 737 MAX 8 crews successfully coped with MCAS operational features, obtaining the incorrect data from the angle-of-attack sensor, and completed the flights uneventfully.

Thus, the EBT concept refocuses the training system on analyzing the original causes of unsuccessful maneuvers (pilot actions), primarily in order to correct inappropriate actions instead of simply completing repeatedly the "correct sequence of actions". The ability to apply correctly the "error analysis" principles is meant to be the key factor in the training process. In this regard, approaches ensuring an unbiased, extensive, objective, and continuous analysis of the pilot's actions are of paramount importance. The given analysis is bound to rely on the factual data of objective control - a big amount of data generated in the course of all the pilot's flight operation (aircraft type training, maintaining qualifications, routine flight operation). One of the most important goals of such an analysis, as it has already been mentioned above, should be developing a well-founded series of recommendations with respect to forming (correction) pilot's professional competencies that ensure safe pilotage capabilities in any circumstances even unknown before. A possible approach to the solution of this problem is presented in this article.

\section{TASK ASSIGNMENT}

The aircraft control problem can be provisionally divided into flight path and pilotage components. The flight path component can be defined as the choice of the right control strategy, in other words, the choice of the correct maneuver. The pilotage component is comprised of selecting by the pilot particular deflections of the aircraft controls (control column, side stick, pedals, throttle lever) that assure the implementation of an assigned flight path (maneuver). With rare exceptions, while piloting the civil aircraft of transport category, the desired flight path is known. So, maneuvering at takeoff and landing stages in the area of the airfield takes place in accordance with the prescribed departure routes SID (Standard instrument departure), arrival procedures STAR (Standard arrival routes instrument) and approach (Approach), including glide slope descent on final (Final Approach Segment). Therefore, the civil aviation pilot makes the main errors while pursuing prescribed flight paths i.e. while addressing the pilotage component of the aircraft control task.

Quality evaluation of piloting component is a complex task currently implemented in sufficiently a narrow sphere by means of analyzing the individual flight parameters in terms not exceeding

\footnotetext{
6 The analysis based evidence personnel training. Implementation Guide. (2014). 1st ed. 2014. International Air Transport Association, $210 \mathrm{p}$.
} 
accepted values. Flight speed, deviation from the glide path (at the points of entry, passing inner and outer beacons, etc.), angle of attack, vertical acceleration, etc. are referred to similar parameters. The carried-out research has shown [8] that the applied tolerance estimates are random and have low correlation with the level of pilot training. Complexity of flight performance assessment for the pilotage component and, accordingly, usage of all the capabilities for such an assessment are specified by a large variety of possible control effects that ensure the implementation of the same flight path with the given accuracy. Generally, each pilot has his own individual manner of piloting [9, 10]. Therefore, from the point of view of searching for capabilities to improve a particular pilot's flight performance it is relevant to develop a methodology to resolve the subsequent tasks:

- validation of the flight performance criterion;

- calculation of the flight performance criterion for a particular pilot;

- calculation of the probability of unsuccessful maneuver completion under given conditions for a particular pilot in order to identify challenges while implementing flight modes;

- giving recommendations concerning the pilot's professional competencies formation (correction).

\section{METHODOLOGY OF RESEARCH}

The content of the proposed methodology is presented in Figure 4.

The input data for this methodology is personalized information obtained from voice and data recorders of the aircraft operated by a particular pilot during flight operation:

- training for an aircraft type;

- maintaining qualifications;

- routine flight operations,

as well as data generated during the pilot's simulator mission. This information is divided into the stages (take-off, climb, etc.) and flight conditions (time of the day, meteorological conditions, failures and their type, etc.).

In addition, the data obtained by means of pilot two models is input data of the methodology:

1) an individual pilot model;

2) a generalized (idealized) pilot model.

The pilot model is a model that simulates pilot response to flight controls deflection under assigned flight conditions, the aircraft state and its attitude. The problems of constructing a pilot model are concerned with of the pilot performance features as a control operator. Among these features we should highlight as follows:

1) discreteness of information perception;

2) a delayed response to the events considering the fact that a delay value can vary in flight;

3 ) erroneous and imprecise flight controls handling - largely depends on the pilot proficiency and his condition;

4) pilot sensitivity thresholds, which vary when the force acting on the pilot changes.

A person ability to be affected by external factors (the intensity of incoming information, the level of fatigue, stress, physical impacts, etc.) determines a probability of pilot's abilities variations as an aircraft control operator during the flight (several flights), which, in turn, defines the pilot model stochastic nature.

In the suggested methodology, the pilot model is used in order to solve the following tasks:

- conducting additional research, in other words, "increasing flight hours" in order to identify potentially dangerous modes for this pilot and their further training on the simulator;

- generalizing an analysis for the pilot models array for the purpose of identifying the best control pattern for each specific situation to create a generalized model of the "best" pilot. 


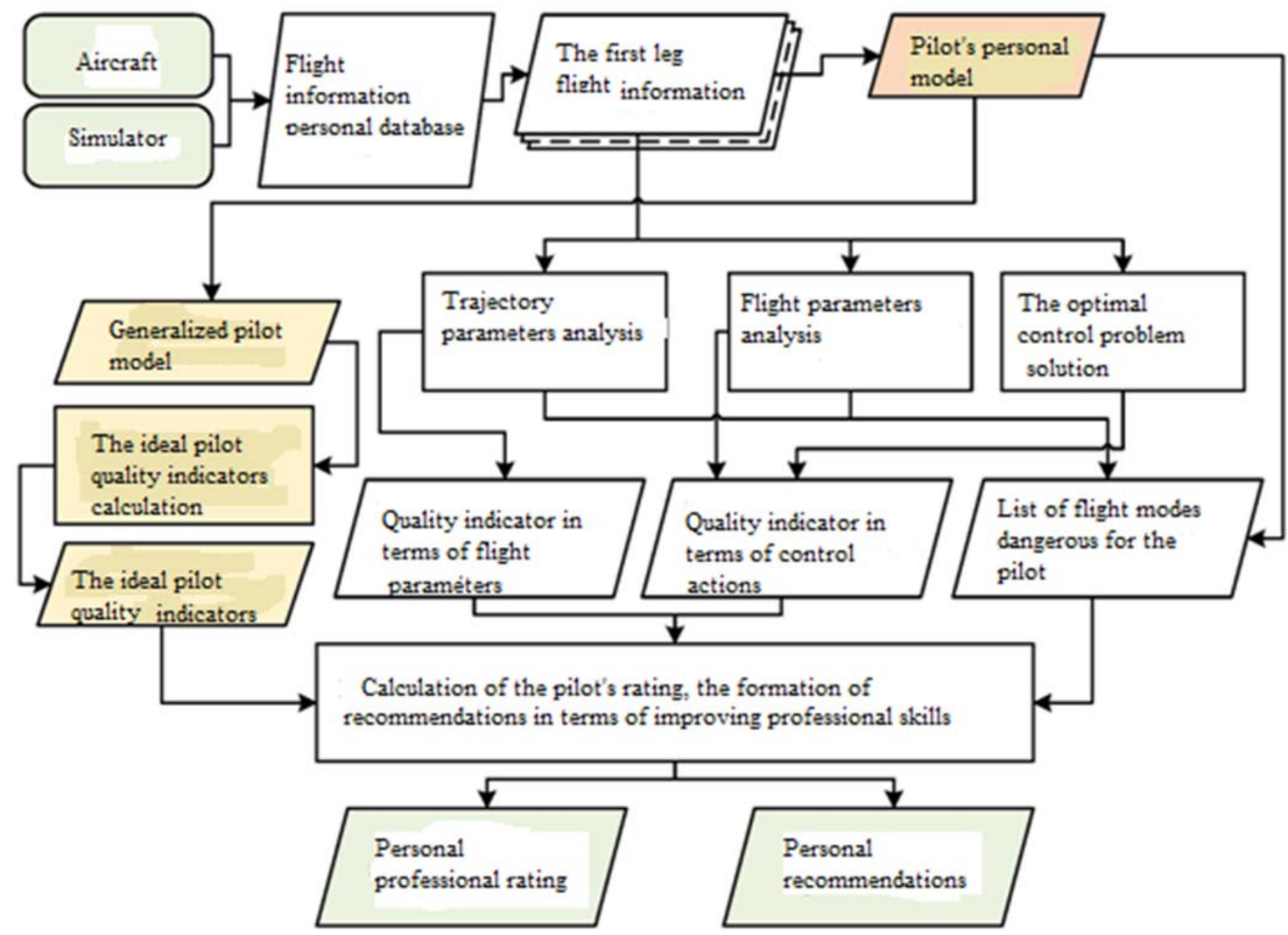

Fig. 4. The content of the methodology for improving the level of flight safety based on the pilot model

The essence of the methodology is as follows.

The information about flight parameters obtained from the aircraft voice and data recorders, the aircraft simulator as well as from the pilot personal model, is analyzed:

1) in terms of trajectory parameters in order to determine their exceeding the established limitations and calculate the corresponding indicator;

2) calculation of the indicator that characterizes the professional competence of aircraft control;

3 ) determination of the number of dangerous flight modes, i.e. the modes in which the flight parameters are close to the limit conditions and their going beyond will pose a threat to flight safety.

The comparative analysis of the different pilots qualitative characteristics, generalization of these indicators allow you:

1) to calculate the best indicator for this group;

2) to create a model of the best pilot for this group - the model of the "ideal" pilot; lot model;

3) to rank pilots according to the proximity of their indicators to the indicators of the "ideal" pi-

4) to offer personal recommendations in terms of improving professional skills.

We will evaluate the flight proficiency using the analysis of the pilot's control actions - flight controls deflections. The relationship between the nature of the flight controls deflections and the flight proficiency is based on the research of the Institute of Aviation and Space Medicine [11]. However, the previously proposed approaches $[8,12-13]$, implementing the given concept, propose to apply the filters in order to separate the trajectory and flight components. In contrast to the known approaches, the proposed method presents the direct calculation of the trajectory component by means of solving the inverse problem of flight dynamics. Let us have a closer look at the specified algorithm. 
The flight path based on the known coordinates is approximated using splines. Let us state that, under the Weierstrass approximating theorem, for any continuous function on the segment, one can choose a sequence of polynomials that converge evenly to this function on the segment [14]. The most "physical" is the representation of the trajectory by cubic splines, which are a piecewise polynomial of the $3^{\text {rd }}$ degree. At a separate section, a cubic spline is a dependency in the form of:

$$
\left\{\begin{array}{l}
x(\tau)=a_{x} \tau^{3}+b_{x} \tau^{2}+c_{x} \tau+d_{x} \\
y(\tau)=a_{y} \tau^{3}+b_{y} \tau^{2}+c_{y} \tau+d_{y} \\
z(\tau)=a_{z} \tau^{3}+b_{z} \tau^{2}+c_{z} \tau+d_{z}
\end{array}\right.
$$

Then, the controlled trajectory parameters (overload and roll) required for the achievement of the specified trajectory are calculated as follows:

$$
\begin{gathered}
n_{y a}=\frac{1}{\cos \gamma_{a}}\left(\frac{V^{2} \theta^{\prime}}{g \sqrt{x^{\prime 2}+y^{\prime 2}+z^{\prime 2}}}+\cos \theta\right) \operatorname{tg} \gamma_{a}=-\frac{\varphi^{\prime} \cos \theta}{\theta^{\prime}+\frac{g \cos \theta \sqrt{x^{\prime 2}+H^{\prime 2}+z^{\prime 2}}}{V^{2}}} \\
\sin \theta=\frac{y^{\prime}}{\sqrt{x^{\prime 2}+y^{\prime 2}+z^{\prime 2}}} \operatorname{tg} \varphi=-\frac{z^{\prime}}{x^{\prime}} \theta^{\prime}=\frac{y^{\prime \prime}\left(x^{\prime 2}+z^{\prime 2}\right)-y^{\prime}\left(x^{\prime} x^{\prime \prime}+z^{\prime} z^{\prime \prime}\right)}{\left(x^{\prime 2}+y^{\prime 2}+z^{\prime 2}\right)^{3 / 2} \cos \theta} \varphi^{\prime}=\frac{-\cos \varphi\left(x^{\prime} z^{\prime \prime}-z^{\prime} x^{\prime \prime}\right)}{x^{\prime 2}}
\end{gathered}
$$

If you know transfer relations for the aircraft control system, you can determine the required flight controls deflections to implement the path. For example, if you know the gradient of a control stick movement concerning overload $X_{b}^{n_{y}}$ you can determine the movement of a control stick required to create an assigned overload $X_{s}=X_{s}^{n_{y}} n_{y}$. form:

Then, as a criterion of quality pilotage component, we will use the criterion of the following

$$
k_{1} \sum \int\left|\frac{U_{\text {current }}^{i}-U_{\text {required }}^{i}}{U_{\text {required }}^{i}}\right| d t+k_{2} S
$$

where $\mathrm{U}_{\text {current, }}^{i} U_{\text {required }}^{i}$ - current and required on the basis of solution of the flight dynamics inverse problem, the $i$ control lever deflection value;

$S$ - the area of the figure made by the required and factual flight paths;

$k_{1}, k_{2}$ - weight coefficients variable depending on the value of $S$ in such a way that in case of slight (acceptable) disagreements between the required and the factual flight paths $k_{1} \rightarrow \max , k_{2} \rightarrow \min$ while under unacceptable variations between the required and the factual flight paths $k_{1} \rightarrow \min , k_{2} \rightarrow \max$.

The key requirement for the mathematical model of the pilot is its sensitivity to changes of the particular pilot's flight technique over time, determined by changes in flight hours, training sessions, the availability of breaks, etc. The most suitable tool to form such an individual model of the pilot will be the utilization of artificial neural networks. The advantages of neural networks over traditional mathematical approaches and expert assessments are the opportunity to use them in order to solve problems with the unknown patterns of the situation development and obvious dependencies between 
input and output data $[15,16]$, which will allow us to create a model of the pilot with individual features of aircraft control.

The proposed method will utilize multilayer neural feed-forward networks [17] (Fig. 5).

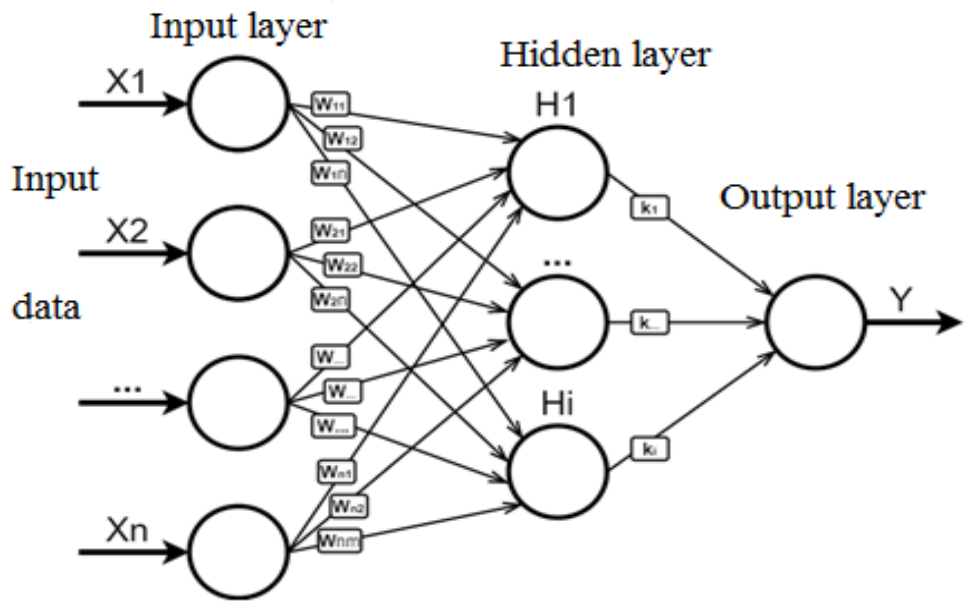

Fig. 5. Multilayer neural feed-forward network

The required number of layers between their input and output, called "hidden" layers, will be clarified in the course of research.

Each artificial neuron is a non-linear function of a single argument $-\mathrm{a}$ linear combination of all input signals (Fig. 6).

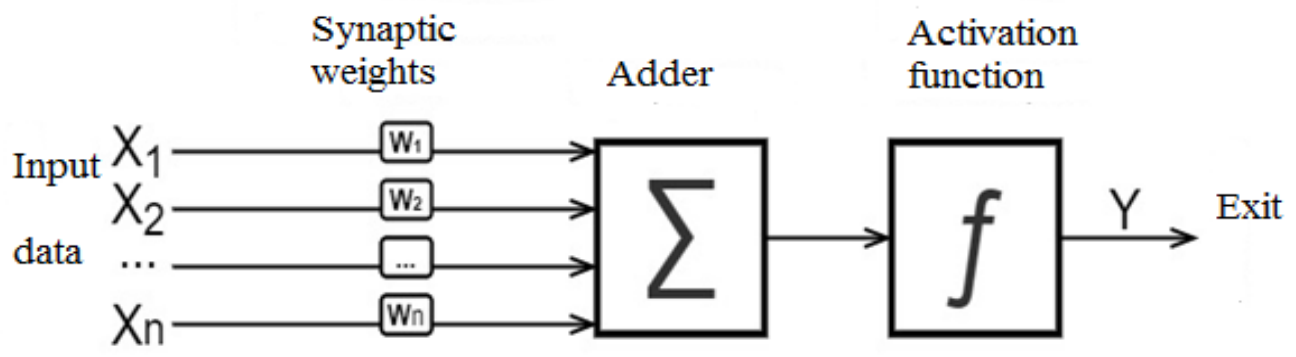

Fig. 6. Artificial neuron with the activation function

Mathematically, an artificial neuron is a weighted integrator and a nonlinear function is applied to its output, which is called the activation function and determined through its inputs and matrix of synaptic weights:

$$
y_{k}^{j+1}=f\left(\sum_{i=1}^{n} \omega_{i} x_{i}+\omega_{0}\right)
$$

where $\omega_{0}-$ a coefficient of neuron bias ( the weight of single input);

$\omega_{i}$ - synaptic weight of $i$ neuron;

$x_{i}$ - input of $i$ neuron;

$n$ - the number of neurons which enter the processed neuron. 
Output of $k$ neuron of $j+1$ layer is calculated as the sum of all its inputs from layer $\mathrm{j}$, to which the activation function is applied, which normalizes the output signal. The most common activation functions are: a nonlinear function with saturation so-called logistic function or sigmoid (Fig. 7b), and a linear rectifier (ReLU) (Fig. 7a).

Mathematically, the sigmoid function is expressed as follows:

$$
f(x)=\sigma(x)=\frac{1}{1+e^{-x}}
$$

The function of the linear rectifier ReLU has the following form:

$$
f(x)=\max (0, x)
$$

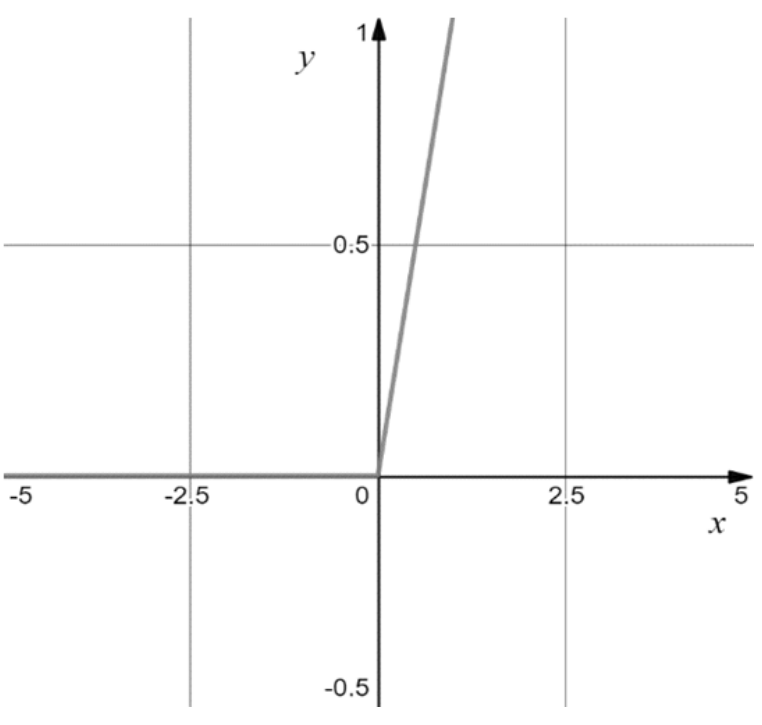

a)

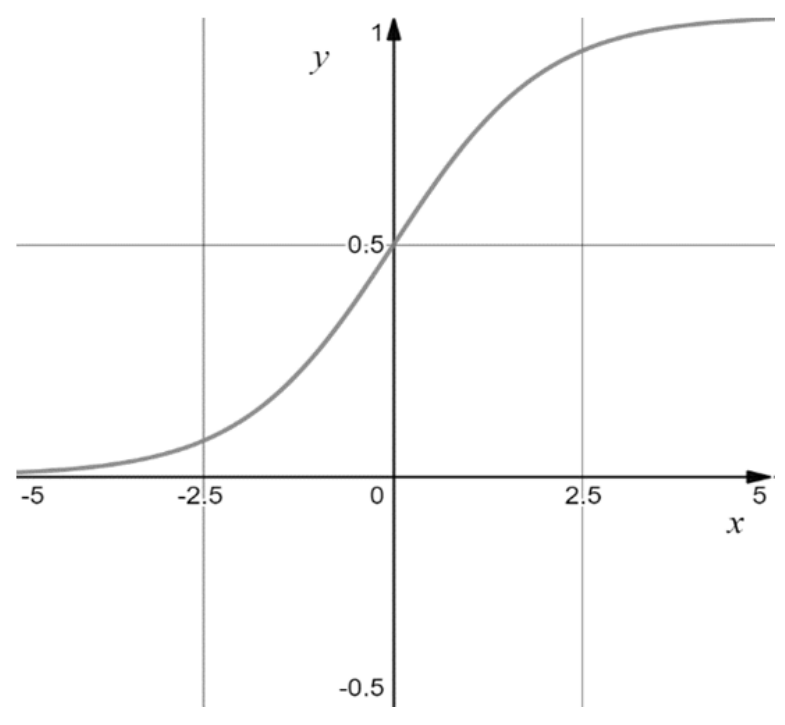

b)

Fig. 7. Activation functions: a) linear rectifier ReLU; b) sigmoidal function

To evaluate the accuracy of neural network learning, the loss (of costs) function is used. The most common loss function is the root-mean-square error (4).

$$
J(\omega)=\frac{1}{2} \sum_{j=1}^{n}\left(\omega_{j} x_{j}^{(i)}-y_{j}^{(i)}\right)^{2}
$$

where $i$ - number of the element;

$n$-number of elements in the learning sample;

$x_{j}^{(i)}$-value of input parameter;

$y_{j}^{(i)}$ - output parameter value from the learning sample.

In this case, the synaptic weights $\omega_{j}$ act as a parameter of the loss function, and learning the neural network according to the objective control data involves correction of the synaptic weights using the method of error back propagation. 
The synaptic weights will be adjusted using the stochastic gradient descent method [17], by adding $\Delta \omega_{i j}$ based on each group of correct answers.

$$
\Delta \omega_{i j}=-\eta \frac{d J}{d \omega_{i j}}
$$

where $0<\eta<1-$ the multiplier that sets up function speed.

The flight parameters are used as input data for the model at the beginning of the maneuver. The output parameters are quality indicators in terms of flight parameters (we use the penalty function for controlled parameters) and the pilotage component.

Summarizing the information for all the individual models, as it has already been mentioned above, according to the considered criteria, the best pilot models for each of the flight segments and input data will be determined, which will allow us to form a model of the best pilot for the given group, or, in other words, a model of the "ideal" pilot.

\section{CONCLUSION}

Taking into consideration the fact that currently the number of accidents and incidents associated with pilot errors remains at a fairly high level. New approaches aimed at improving the level of flight safety are relevant and in demand. One of the promising approaches to solve this problem is the concept of personnel training based on evidence-based analysis (EBT). For the successful implementation of this concept the availability of tools that provide a continuous analysis of the pilot actions both in terms of identifying errors and predicting possible risks in various flight situations as well as identifying potential areas for improvement and adjusting the pilot's professional competencies is extremely important. This article proposes an approach designed to solve the tasks mentioned above and provides, firstly, comparative indicators calculation of pilots proficiency and, secondly, special studies with the aim of identifying flight modes potentially dangerous or difficult for implementation by the pilot. The proposed approach is based on the aircraft means of objective control data, simulators, as well as on the data obtained by specially developed pilot models and flight dynamics inverse problem solution. Scheduling the events aimed at improving (maintaining) the pilots' proficiency will facilitate flight safety improvement without significant material costs using the results obtained by means of the proposed methodology.

\section{REFERENCES}

1. Kelly, D. and Efthymiou, M. (2019). An analysis of human factors in fifty controlled flight into terrain aviation accidents from 2007 to 2017. Journal of Safety Research, vol. 69, pp. 155-165. DOI: 10.1016/j.jsr.2019.03.009

2. Krikunov, K.N. (2013). Problems of training of commercial aviation pilots. Bulletin of the South Ural State University. Series: Education. Educational Sciences, vol. 5, no. 2, pp. 79-87. (in Russian)

3. Bolshedvorskaya, L.G. and Miroshnichenko, A.A. (2009). Economic and methodological aspects of simulator training of aircraft crew aircraft grew members. Nauchnyy Vestnik MGTU GA, no. 143, pp. 55-62. (in Russian)

4. Krikunov, K.N. (2013). To the question of problems with training pilots of civil aviation. Bulletin of the South Ural State University. Series: Education. Educational Sciences, vol. 5, no. 1, pp. 147-150. (in Russian)

5. Karpova, L.I. and Nikitin, D.A. (2011). The training of civil aviation personnel is a pledging of security of air transportation. Nauchnyy Vestnik MGTU GA, no. 166, pp. 102-106. (in Russian) 
6. Petrunin, S.V. and Bolshedvorskaya, L.G. (2011). The organization of training of flight crew members by airlines depending on the program complexity. Nauchnyy Vestnik MGTU GA, no. 167, pp. 21-26. (in Russian)

7. Moroney, W.F. and Moreney, B.W. (1999). Flight simulation. In: handbook of aviation human factors, pp. 355-388.

8. Tikhiy, I.I., Kashkovsky, V.V. and Poluektov, S.P. (2009). Estimation of quality of piloting in the mode flight on glide path. Nauchnyy Vestnik MGTU GA, no. 138, pp. 191-197. (in Russian)

9. Evdokimenkov, V.N., Kim, R.V. and Jakimenko, V.A. (2016). Technical and biological parts of ergatic system "pilot-aircraft" accommodation using artificial neural network approach. Trudy MAI, no. 89. 21 p. Available at: http://trudymai.ru/upload/iblock/eaa/evdokimenkov_kim_ yakimenko_rus.pdf?lang=ru\&issue $=89$ (accessed: 21.02 .2021 ). (in Russian)

10. Gladkov, B.M. (1991). Avtomatizirovannaya otsenka natrenirovannosti letchikov s ispolzovaniyem pokazateley upravlyayushchikh vozdeystviy [Automated training evaluation of pilots using control actions indicators]. Nauchno-metodicheskiye materialy po problemam obespecheniya bezopasnosti poletov. Irkutskoye VVAIU, pp. 73-79. (in Russian)

11. Rudnyy, N.M., Kopanev, V.I., Chernyakov, I.N. and others. (1986). Aviatsionnaya meditsina [Aviation medicine], in Rudnyy N.M. (Ed.). Moscow: Meditsina, 577 p. (in Russian)

12. Frolov, N.I. (1978). Puti izucheniya rabotosposobnosti letchika v polete [Ways to study the pilot flight performance]. Kosmicheskaya biologiya i aviakosmicheskaya meditsina, vol. 12, no. 1, pp. 3-11. (in Russian)

13. Poluehktov, S.P., Kashkovskij, V.V., Tikhij, I.I. and Lapin, I.P. (2011). Method of assessing quality of piloting aeroplane by pilot during landing phase based on data from standard onboard recording device. Patent RU, no. 2436164 C1, December 10, 2011. (in Russian)

14. Fikhtengolts, G.M. (2020). Kurs differentsialnogo i integralnogo ischisleniya: uchebnik dlya vuzov. $V 3$ tomakh. Tom 3 [Differential and integral calculus course: Textbook for Universities]. 11th ed., ster. Moscow: Lan, 656 p. (in Russian)

15. Ied, K., Maslennikova, G.E. and Tyumentsev, Ju.V. (2020). Computing safe parameters of maneuver commencing of aerobatics aircraft using artificial neural network. Aerospace MAI Journal, vol. 27, no. 2, pp. 169-184. DOI: 10.34759/vst-2020-2-169-184 (in Russian)

16. Vorobyev, V.V., Beliatskaya, A.P. and Supolka, A.A. (2020). Methodic aspects of aircraft glide slope correction for prevention of cfit category accidents during pre-landing descent. Civil Aviation High Technologies, vol. 23, no. 4, pp. 33-44. DOI: 10.26467/2079-0619-2020-23-4-33-44 (in Russian)

17. Haykin, S. (1999). Neural networks: a comprehensive foundation. 2nd ed. Hamilton, Ontario, Canada: Prentice Hall, 842 p.

\section{INFORMATION ABOUT THE AUTHORS}

Anton D. Barabash, Post-Graduate Student, Moscow State Technical University of Civil Aviation, user-adm@mail.ru.

Sergey F. Borodkin, Candidate of Technical Sciences, Associate Professor of the Aerodynamics, Design and Aircraft Strength Chair, Moscow State Technical University of Civil Aviation, s.borodkin@mstuca.aero.

Mikhail A. Kiselev, Doctor of Technical Sciences, Professor, Head of the Aerodynamics, Design and Aircraft Strength Chair, Moscow State Technical University of Civil Aviation, m.kiselev@mstuca.aero.

Yuriy V. Petrov, Doctor of Technical Sciences, Professor, Head of Technical Mechanics and Engineering Graphics Chair, Moscow State Technical University of Civil Aviation, doctor561@rambler.ru. 


\title{
МЕТОДИКА ПОВЫШЕНИЯ УРОВНЯ БЕЗОПАСНОСТИ ПОЛЕТОВ НА ОСНОВЕ МОДЕЛИ ПИЛОТА
}

\author{
А.Д. Барабаш ${ }^{1}$, С.Ф. Бородкин ${ }^{1}$, М.А. Киселев ${ }^{1}$, Ю.В. Петров ${ }^{1}$ \\ ${ }^{1}$ Московский государственный технический университет гражданской авиации, \\ 2. Москва, Россия
}

Несмотря на регулярно предпринимаемые усилия со стороны национальных регуляторов, Международной организации гражданской авиации и Международной ассоциации воздушного транспорта (ИКАО и ИАТА), разработчиков авиационной техники, подавляющее большинство авиационных происшествий и инцидентов продолжает происходить по причине человеческого фактора. Так, с течением времени конструкция и надежность воздушных судов (ВС) неуклонно и существенно улучшается, но, тем не менее, авиационные происшествия происходят все чаще и чаще, в том числе и на исправных ВС. Ярким тому подтверждением служит факт того, что столкновение с землей в управляемом полете (CFIT) остается одной из самых распространенных причин авиационных происшествий. Это обусловлено целым рядом проблем, требующих поиска комплексных, взаимоувязанных решений. Среди указанных проблем следует выделить все возрастающую сложность ВС как технической системы, а также практически неизменные вот уже более полувека подходы к подготовке пилотов на тип и к поддержанию их квалификации, основанные на заранее определенных сценариях, формируемых исходя из предшествующего опыта эксплуатации ВС. Одним из возможных путей выхода из создавшейся ситуации может быть внедрение так называемой концепции подготовки персонала на основе анализа фактических данных (ЕВТ), в основе которой лежит не стремление заучить определенный перечень упражнений, а развить у каждого конкретного пилота компетенции, которые обеспечили бы ему возможности справиться с любой непредсказуемой ситуацией. Ключевая особенность ЕВТ заключается в переориентации на анализ первопричин неуспешно выполненных маневров (действий пилота), в первую очередь для того, чтобы откорректировать несоответствующие действия, вместо того, чтобы просто отработать повторно «правильную последовательность действий». В этой связи особую значимость приобретают инструменты, обеспечивающие непрерывный анализ действий пилота на предмет выявления ошибок для своевременной корректировки (формирования) профессиональных компетенций пилота. В статье описывается содержание методики, конечной целью которой является выработка основанных на сравнительной оценке качества пилотирования конкретного пилота рекомендаций по совершенствованию профессиональных компетенций пилота, базирующаяся на обобщенной и персонализированных моделях пилота, а также решении обратной задачи динамики полета.

Ключевые слова: безопасность полетов, человеческий фактор, подготовка персонала, анализ фактических данных, динамика полета, модель пилота.

\section{СПИСОК ЛИТЕРАТУРЫ}

1. Kelly D., Efthymiou M. An analysis of human factors in fifty controlled flight into terrain aviation accidents from 2007 to 2017 // Journal of Safety Research. 2019. Vol. 69. Pp. 155-165. DOI: $10.1016 /$ j.jsr.2019.03.009

2. Крикунов К.Н. Проблемы системы подготовки пилотов гражданской авиации // Вестник ЮУрГУ. Серия: Образование. Педагогические науки. 2013. Т. 5, № 2. С. 79-87.

3. Большедворская Л.Г., Мирошниченко А.А. Экономические и методологические аспекты тренажерной подготовки летного состава // Научный Вестник МГТУ ГА. 2009. № 143. C. 55-62.

4. Крикунов К.Н. К вопросу о проблемах подготовки пилотов гражданской авиации // Вестник ЮУрГУ. Серия: Образование. Педагогические науки. 2013. Т. 5, № 1. С. 147-150.

5. Карпова Л.И., Никитин Д.А. Подготовка специалистов гражданской авиации гарантия безопасности воздушных перевозок // Научный Вестник МГТУ ГА. 2011. № 166. C. 102-106.

6. Петрунин С.В., Большедворская Л.Г. Организация процесса подготовки летного состава авиакомпании в зависимости от сложности программы // Научный Вестник МГТУ ГА. 2011. № 167. C. 21-26.

7. Moroney W.F., Moreney, B.W. Flight simulation. In: Handbook of aviation human factors, 1999. Pp. 355-388. 
8. Тихий И.И., Кашковский В.В., Полуэктов С.П. Оценка качества пилотирования в режиме полета по глиссаде // Научный Вестник МГТУ ГА. 2009. № 138. С. 191-197.

9. Евдокименков В.Н., Ким Р.В., Якименко В.А. Согласование технического и биологического сегментов эргатической системы «самолет-летчик» с использованием нейросетевого подхода [Электронный ресурс] // Труды МАИ. 2016. № 89. 21 с. URL: http://trudymai.ru/upload/iblock/eaa/evdokimenkov_kim_yakimenko_rus.pdf?lang=ru\&issue=89 (дата обращения: 21.02.2021).

10. Гладков Б.М. Автоматизированная оценка натренированности летчиков с использованием показателей управляющих воздействий // Научно-методические материалы по проблемам обеспечения безопасности полетов. Иркутское ВВАИУ. 1991. С. 73-79.

11. Рудный Н.М., Копанев В.И., Черняков И.Н. и др. Авиационная медицина / Под ред. Н.М. Рудного. М.: Медицина, 1986. 577 с.

12. Фролов Н.И. Пути изучения работоспособности летчика в полете // Космическая биология и авиакосмическая медицина. 1978. Т. 12, № 1. С. 3-11.

13. Полуэктов С.П. Способ оценивания качества пилотирования самолета летчиком на этапе посадки по данным штатного бортового устройства регистрации / С.П. Полуэктов, B.В. Кашковский, И.И. Тихий, И.П. Лапин. Патент RU № 2436164 C1, 10.12.2011.

14. Фихтенгольц Г.М. Курс дифференциального и интегрального исчисления: учебник для вузов. 11-е изд., стер. В 3-х т. Т. 3. М.: Лань, 2020. 656 с.

15. Иед К., Масленникова Г.Е., Тюменцев Ю.В. Расчет безопасных параметров начала маневра спортивных самолетов с использованием искусственной нейронной сети // Вестник Московского авиационного института. 2020. Т. 27, № 2. С. 169-184. DOI: 10.34759/vst-2020-2-169-184

16. Воробьев В.В., Беляцкая А.П., Суполка А.А. Методика устранения отклонений воздушного судна при предпосадочном снижении для предотвращения происшествий категории CFIT // Научный Вестник МГТУ ГА. 2020. Т. 23, № 4. С. 33-44. DOI: 10.26467/20790619-2020-23-4-33-44

17. Haykin S. Neural networks a comprehensive foundation. 2nd ed. Hamilton, Ontario, Canada: Prentice Hall, 1999. 842 p.

\section{СВЕДЕНИЯ ОБ АВТОРАХ}

Барабаш Антон Дмитриевич, аспирант МГТУ ГА, user-adm@mail.ru.

Бородкин Сергей Филиппович, кандидат технических наук, доцент кафедры аэродинамики, конструкций и прочности летательных аппаратов МГТУ ГА, s.borodkin@mstuca.aero.

Киселев Михаил Анатольевич, доктор технических наук, профессор, заведующий кафедрой аэродинамики, конструкций и прочности летательных аппаратов МГТУ ГА, m.kiselev@mstuca.aero.

Петров Юрий Владимирович, доктор технических наук, профессор, заведующий кафедрой технической механики и инженерной графики МГТУ ГА, doctor561@rambler.ru.

$\begin{array}{llll}\text { Поступила в редакцию } & 01.04 .2021 & \text { Received } & 01.04 .2021 \\ \text { Принята в печать } & 20.05 .2021 & \text { Accepted for publication } & 20.05 .2021\end{array}$

